Canadian Studies in Population, Vol. 30(1), 2003, pp. 159-162

\title{
The Crossing of Paths: Interactions with Anatole Romaniuk on Africa
}

John C. Caldwell

Australian National University

Canberra, Australia

Until 1961 I had worked on the demography of Southeast Asia. Then a quantum change occurred when I agreed to go, wholly unprepared, to take up the Population Council post at the University of Ghana (previously occupied by Frank Lorimer and Dov Friedlander, and later by Ian Pool). An orientation course was needed and Frank Notestein decided that I, together with Pat Caldwell and our children, should travel from Australia to Ghana in early 1962 by way of Princeton University's Office of Population Research where the African Project (ultimately to produce The Demography of Tropical Africa) was in its early stages. So early that we learnt little about what it would cover, but we had a marvelous introduction to the subject of living and researching in subSaharan Africa, talking to those who were the pioneers: Anatole, Bill Brass, Etienne van de Walle and Karol Krotki. Anatole, in his slightly diffident way, was a mine of information. Admittedly, we thought the descriptions were of anciens regimes, colonial Africa, for by this time Nkrumah's Ghana was independent while the post-Lumumba Congo was changing every day. Ultimately we would find that, in terms of social demography, there were no discontinuities. 
John C. Caldwell

Our most important discussions occurred at The First African Population Conference, which Chukuka Okonjo and I organized (with Population Council support) at the University of Ibadan in the first week of January 1966. It was a time of heightened awareness, as political disorders in that part of Nigeria set the country on the path to civil war. Each night we watched the glow of parts of Ibadan City burning. We now had undertaken sufficient research in Ghana and knew Nigeria well enough to be able to talk to Anatole in his own language. But Pat and I had worked mostly on fertility, conforming to Anatole's charge that the new breed of African demographers had forgotten the old colonial worries about low fertility and disappearing peoples (Romaniuk 1968a: 214). His paper on "Infertility in tropical Africa" began the process of putting the balance right. He drew on many sources, but especially on the 1955-57 Demographic Survey of the Congo which he directed, to describe populations in provinces like Bas Uele where the crude birth rate was 20 and where 50 percent of women reached menopause without bearing a child. Almost one-quarter of the Congo had recorded crude birth rates under 35. He drew on published and unpublished sources to identify other sterile populations in Zanzibar, Tanzania, coastal Kenya, Southern Uganda, the Central African Republic, Gabon, Cameroon, adjoining parts of Sudan (identified by Karol Krotki) and even areas in West Africa. He successively ruled out possible causes, and finally focused on births outside marriage, multiple sexual partners and "conjugal mobility" and their geographical associations with STD levels and the extent of sterility.

In a sense, he pioneered the work that was to lead us and others to the research of the 1980s and 1990s on the behavioral context of the African AIDS epidemic. He influenced our research in the late 1970s on sterility in Nigeria and our report in 1979 to a conference in Franceville, Gabon which marked the opening of a research station on human sterility (Caldwell and Caldwell 1983). We draw on his work and that of others to explore the situation in the major sterility areas of Middle Africa and broadly supported his conclusions. What we really drew on at the Ibadan Conference and on other occasions was only to some extent in his written papers but mostly on his humane, civilized and introspective discussion of African society and demographic behavior. It should be noted that in his Ibadan paper he called for the construction of a "normal fertility standard", a concept close to Louis Henry's "natural fertility" but meaning fertility constrained neither by voluntary fertility control nor by sterilizing disease.

Anatole was to analyze the 1955-57 demographic survey in The Demography of Tropical Africa at some length. Indeed, his is the longest chapter in that large book, constituting one-fifth of it. In some ways more important, if less accessible to those of us who read book-length French slowly and painfully, was his major work, also appearing in 1968, La fécondité des populations congolaises.

There was more interaction between us, and with others on the issue of fertility rise preceding fertility decline in the early stages of demographic transition. We 
The Crossing of Paths:

Interactions with Anatole Romaniuk on Africa

had focused on shortening periods of postpartum sexual abstinence and lactation and their impact, especially with such elements of modernization as schooling and urbanization, in research programs in Nigeria in 1973 and 1974, reported in Caldwell and Caldwell (1977, 1981) and Caldwell and McDonald (1982). Anatole drew on Congo material for his 1980 paper, "Increase in natural fertility during the early stages of modernization: evidence from an African case study, Zaire", which was based on a paper he gave to the 1978 PAA meeting in Atlanta. He reported that he had already discussed the topic in a paper on Canadian Indians (Romaniuk 1974) but we had missed it. Progressively, we cited each other.

I particularly remember a day spent talking to Anatole in New York in 1967 or 1968 when I was the Population Council's Regional Director for Africa and he was with the University of Ottawa. We explored African demography thoroughly, but repeatedly he returned to the theme that the time had come to switch our interests to the demography of Eastern Europe. Neither of us did so, but others, perhaps some inspired by Anatole, were to take that route. It is for these long probing discussions that I most came to value his friendship.

John C. Caldwell

Canberra, August 2001

\section{References:}

Brass, W., Coale, A.J., Demeny, P., Heisel, D.F., Lorimer, F., Romaniuk, A. \& van de Walle, E., 1968, The Demography of Tropical Africa, Princeton University Press, Princeton.

Caldwell, J.C. \& Caldwell, Pat, 1977. "The role of marital sexual abstinence in determining fertility: a study of the Yoruba in Nigeria," Population Studies 31 (2): 193-217.

Caldwell, J.C. \& Caldwell, Pat, 1981. "Cause and sequence in the reduction of postnatal abstinence in Ibadan City, Nigeria", in Hilary J. Page and Ron Lesthaeghe (eds.) Child-spacing in Tropical Africa: Traditions and Change. Academic Press, London. Pp. 181-199.

Caldwell, J.C. \& Caldwell, Pat, 1983. "The demographic evidence for the incidence and cause of abnormally low fertility in tropical Africa,"

World Health Statistics Quarterly 36 (1): 2-21. 
John C. Caldwell

Caldwell, J.C. \& McDonald, P.F., 1982. "Influences of maternal education on infant and child mortality: levels and causes," Health Policy and Education 2: 251267.

Caldwell, J.C. \& Okonjo, C., 1968. The Population of Tropical Africa. Longmans, Green, London.

Romaniuk, A., 1968a. "Infertility in tropical Africa" in Caldwell and Okonjo (eds.) The Population of Tropical Africa. Longmans, Green, London. Pp. 214-224.

Romaniuk, A. 1968b. "The demography of the Democratic Republic of the Congo" in Brass et al. The Demography of Tropical Africa, Princeton University Press, Princeton. Pp. 241-341.

Romaniuk, A., 1968c. La Fécondité des Populations Congolaises. Mouton, Paris.

Romaniuk, A., 1974. "Modernization and fertility: the case of the James Bay Indians," Canadian Review of Sociology and Anthropology 11 (4): 334-359.

Romaniuk, A., 1980. "Increase in natural fertility during the early stages of modernization: evidence from an African case study, Zaire," Population Studies 34 (2): 293-310. 